\title{
Article
}

\section{Relationship between the structure and activity of ruthenium catalysts in the catalytic ozonation of dimethyl phthalate}

\author{
WANG Jianbing a,*, WANG Can a, YANG Chunli a , WANG Guoqing a , ZHU Wanpeng b \\ a School of Chemical and Environmental Engineering, Beijing Campus, China University of Mining and Technology, Beijing 100083, China \\ ${ }^{\mathrm{b}}$ School of Environment, Tsinghua University, Beijing 100084, China
}

\section{A R T I C L E I N}

\section{Article history:}

Received 31 August 2012

Accepted 30 October 2012

Published 20 February 2013

\section{Keywords:}

Catalytic ozonation

Dimethyl phthalate

Ruthenium

Activated carbon

\begin{abstract}
A B S T R A C T
Ruthenium catalysts on various activated carbon (AC) supports were prepared using conventional calcination and microwave irradiation. Their activity in the catalytic ozonation of dimethyl phthalate was studied. The relationship between the structure and activity was investigated. All the supports and catalysts increased total organic carbon removal. The activity order was $\mathrm{Ru} / \mathrm{coal}-\mathrm{AC}>$ nutshell-AC > Ru/nutshell-AC > Ru/coconut-AC $\approx$ coal-AC > coconut-AC. The supported Ru particles diffused into the macropores, which increased mass transfer resistance in catalytic ozonation and decreased the probability that the reactants can contact the active phase on the interior surface. This was one reason why the activity of nutshell-AC and $\mathrm{Ru} /$ nutshell-AC was lower than that of $\mathrm{Ru} /$ coal-AC. A difference in Ru dispersion on the surface of the catalyst also caused the activity difference. The active phase on the surface of nutshell-AC can be changed by microwave irradiation, which caused $\mathrm{Ru} /$ nutshell-AC to even be less active than the corresponding support. As compared to the use of conventional calcination, the use of microwave irradiation enhanced the metal dispersion and catalytic activity of Ru/coal-AC.
\end{abstract}

(C) 2013, Dalian Institute of Chemical Physics, Chinese Academy of Sciences. Published by Elsevier B.V. All rights reserved.

\section{Introduction}

In recent years, endocrine disruptors have severely polluted drinking water. Most of these exist in drinking water in very low concentrations and are very recalcitrant. Conventional processes cannot easily remove them from water. Ozonation is an effective means for the removal of these organic pollutants. However, the mineralization rate of organic compounds into $\mathrm{CO}_{2}$ and $\mathrm{H}_{2} \mathrm{O}$ by ozonation is not very high. Catalytic ozonation is more effective for the mineralization of organic compounds, and TOC removal by catalytic ozonation is much more effective than that by ozonation alone. Catalytic ozonation (especially by solid catalysts) is an object of intense research in the field of ozonation [1]. The main solid catalysts for ozonation include metal oxides (e.g. $\mathrm{Fe}_{2} \mathrm{O}_{3}, \mathrm{MnO}_{2}, \mathrm{Al}_{2} \mathrm{O}_{3}, \mathrm{Ce}_{2} \mathrm{O}_{3}, \mathrm{WO}_{3}-\mathrm{TiO}_{2}$, and $\mathrm{Ce}_{\mathrm{x}} \mathrm{Zr}_{1-\mathrm{x}} \mathrm{O}_{2}$ ) [2-7], supported metals or metal oxides (e.g. Fe/AC, $\mathrm{Fe}_{2} \mathrm{O}_{3} / \mathrm{Al}_{2} \mathrm{O}_{3}, \mathrm{Cu} / \mathrm{Al}_{2} \mathrm{O}_{3}, \mathrm{Ru} / \mathrm{AC}, \mathrm{MnO}_{2} / \mathrm{Al}_{2} \mathrm{O}_{3}$, and $\mathrm{RuO}_{2} / \mathrm{Al}_{2} \mathrm{O}_{3}$ ) [8-14] and some porous materials (e.g. AC, CNTs, and zeolites) [15-17]. Among these, ruthenium supported on activated carbon was reported to be one of the most promising catalysts. Ruthenium catalysts for the ozonation process have been studied, but the relationship between the activity and structure of the catalyst has been rarely studied. In catalytic ozonation, ozone first adsorbs on sites on the surface of the catalyst, which include metal oxidized/reduced states [18], Lewis acid/alkali centers [2,19], and non-dissociated hydroxyl groups [20]. After its adsorption, ozone is decomposed into hydroxyl radicals and reactions then occur. These reactions include the reactions

\footnotetext{
* Corresponding author. Tel./Fax: +86-10-62339087; E-mail: wangjb@cumtb.edu.cn

This work was supported by the National Natural Science Foundation of China (20907072).

DOI: 10.1016/S1872-2067(11)60479-8 | http://www.sciencedirect.com/science/journal/18722067 | Chin. J. Catal., Vol. 34, No. 2, February 2013
} 
between hydroxyl radicals and organic compounds in aqueous solution, reactions between the byproducts produced on the catalyst surface and organic compounds in aqueous solution, reactions between the byproducts produced on the catalyst surface and organic compounds adsorbed on the catalyst surface, and reactions between hydroxyl radicals and organic compounds adsorbed on the catalyst surface. Reaction mechanisms that have been reported were based on many assumptions and much uncertainty. In these reaction mechanisms, the microscopic reaction mechanism on the catalyst surface is hard to interpret. Thus an investigation of the relationship between the property and structure of the catalyst is significant for the development of more active catalysts.

In this study, ruthenium catalysts supported on various activated carbons were prepared by using the microwave and conventional heating methods. Their activities in the catalytic ozonation of dimethyl phthalate (DMP) in aqueous solution were studied. The effect of catalyst preparation on the structure of the catalyst and the relationship between the structure and activity were investigated.

\section{Experimental}

\subsection{Catalyst preparation}

Three kinds of pelletized activated carbon were used as the supports of the catalysts. These were commercial nutshell-AC, coconut-AC, and coal-AC, which were purchased from Jiangyan Chemical Auxiliary Agent Factory (Jiangyan, China). Before use, the carbon supports were thoroughly washed with distilled water and then dried. $\mathrm{Ru} / \mathrm{AC}$ catalysts were prepared by the impregnation of the activated carbon supports with an aqueous solution of ruthenium chloride (AR). After impregnation for 24 $\mathrm{h}$, the catalyst was dried at $100{ }^{\circ} \mathrm{C}$. It was then irradiated in a microwave heating reactor (Fig. 1) for 3 min. For the microwave irradiation, $20 \mathrm{~g}$ of catalyst was loaded into a quartz reactor with a diameter of $32 \mathrm{~mm}$ and height of $300 \mathrm{~mm}$. The distance between the bottom of the quartz reactor and the bottom of the microwave oven (Sanyo, EM-202MS1, China) was

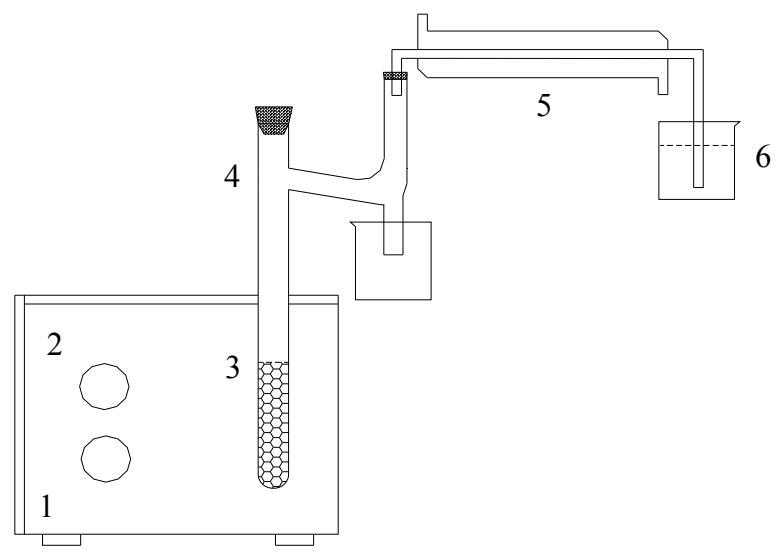

Fig. 1. Schematic of the microwave irradiation apparatus used for catalyst preparation. 1-Microwave oven; 2-Power regulator; 3-Catalyst bed; 4-Quartz reactor; 5-Cooling reflux device; 6-Adsorption bottle of waste liquid.
$20 \mathrm{~mm}$. The height of the microwave oven was $300 \mathrm{~mm}$. The catalyst bed was completely inside the microwave oven. A cooling reflux device was used to make sure that the water vapor produced during microwave irradiation was completely condensed into the liquid.

In order to study the effect of the heating method on the structure and activity of the catalyst, one portion of the coal-AC support was treated by the conventional calcination method but not the microwave irradiation method. For the preparation of $\mathrm{Ru} / \mathrm{Coal}-\mathrm{AC}$ with the conventional calcination method, the catalyst was placed in a muffle furnace after ruthenium impregnation and calcined for $3 \mathrm{~h}$. During calcination, $\mathrm{N}_{2}$ was introduced into the muffle furnace at a flow rate of $1 \mathrm{~L} / \mathrm{min}$. The calcination temperature for the study included 300,400 , 500,600 , and $700{ }^{\circ} \mathrm{C}$. The activities of the catalysts prepared at different calcination temperatures and microwave powers were compared. The nominal ruthenium loading for all the catalysts was $0.5 \%$. The actual loading amount was measured by sequential X-ray fluorescence (XRF) spectrometry (Shimadzu, XRF-1700, Japan). The differences between the nominal and actual loadings were less than $5 \%$.

\subsection{Catalyst assessment}

Ozonation and catalytic ozonation were carried out in a semi-batch reactor described elsewhere [14]. Before reaction, $1000 \mathrm{ml}$ of DMP aqueous solution (the concentration is $5 \mathrm{mg} / \mathrm{L}$ and initial $\mathrm{pH}$ was 6.6) was introduced into the reactor. In the catalytic ozonation experiments, $2 \mathrm{~g} / \mathrm{L}$ catalyst was introduced into the reactor just before ozone was fed in. Then $\mathrm{O}_{3}$ was continuously bubbled into the reactor at a rate of $195 \mathrm{mg} / \mathrm{h}$. The gas pressure was $0.04 \mathrm{MPa}$ and the flow rate was $400 \mathrm{ml} / \mathrm{min}$. The reaction temperature was kept at $(15 \pm 0.5){ }^{\circ} \mathrm{C}$ by a temperature control device [14]. The total organic carbon (TOC) was determined with the NPOC method at different time intervals.

\subsection{Catalyst characterization and analytical methods}

The surface area was determined from the BET equation using $\mathrm{N}_{2}$ adsorption isotherms at $-196{ }^{\circ} \mathrm{C}$ on a Micromeritics ASAP 2010 instrument. The volumes of the mesopores and macropores were determined by mercury porosimetry using a Quantachrome Autoscan 33 apparatus. X-ray diffraction (XRD) patterns were recorded on a diffractometer (Rigaku, D/max-RB, Japan) using $\mathrm{Cu} K_{\alpha}$ radiation $(\lambda=1.5418 \mathrm{~nm})$ with a tube voltage of $40 \mathrm{kV}$, tube current of $100 \mathrm{~mA}$, scanning range of $10^{\circ}-80^{\circ}$, and scanning speed of $6^{\circ} \mathrm{s}$. The surface morphologies of the catalysts were analyzed using a Hitachi S-5500 field emission scanning electron microscope (SEM). The ruthenium metal was determined by the difference in illumination in the imaging region of backscattered electrons. Boehm titration to determine basic groups was carried out by a procedure with $\mathrm{HCl}(0.02 \mathrm{~mol} / \mathrm{L})$ neutralization described elsewhere [21,22].

The concentration of ozone in the gas was measured with the iodometric method [23].The TOC content was analyzed with a TOC analyzer (Shimadzu,TOC-Vwp, Japan). 


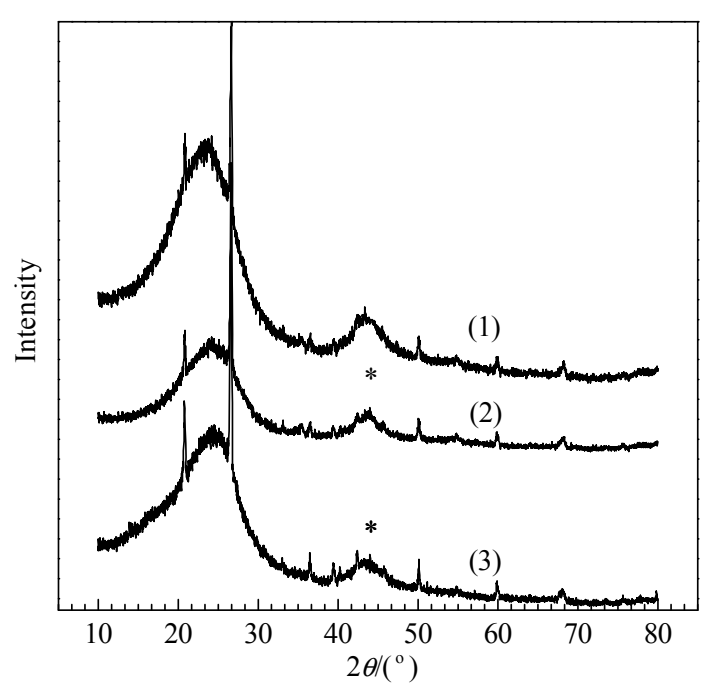

Fig. 2. XRD patterns of coal-AC (1) and Ru/coal-AC prepared by microwave heating (2) and conventional heating (3).

\section{Results and discussions}

\subsection{Results of catalyst characterization}

Figure 2 gives the XRD patterns of the coal-AC and $\mathrm{Ru} /$ coal-AC catalysts prepared by microwave heating and conventional heating. The Ru phase $\left(2 \theta=44.0^{\circ}\right)$ was observed in the XRD patterns of $\mathrm{Ru} / \mathrm{Coal}-\mathrm{AC}$. The peaks were very weak, which was probably because of the low loading of ruthenium and its high dispersion. During the heating treatment, ruthenium was prevented from being oxidized by the reduction activity of the activated carbon.

The characterization of the various activated carbon supports and catalysts are shown in Tables 1 and 2. From Table 1, it can be seen that all the supports and catalysts had high surface areas in the range of 700-1000 $\mathrm{m}^{2} / \mathrm{g}$. Generally, the surface areas of the carbon-supported catalysts were less than those of their supports since some pores of the activated carbon were clogged by metal particles. In this study, the surface areas and macropores of $\mathrm{Ru} /$ coconut- $\mathrm{AC}$ and $\mathrm{Ru} /$ coal-AC were both less than those of their respective supports (Table 1). However, the surface area of $\mathrm{Ru} /$ nutshell-AC was larger than that of the nutshell-AC carbon support, which indicated that the pores of nutshell-AC were enlarged by the microwave irradiation, and its surface structure was changed to some extent after it was treated by microwave irradiation. The data that $\mathrm{Ru} /$ nutshell-AC had a much smaller surface basic group concentration than nutshell also showed this. The comparison between nutshell-AC with and without microwave irradiation treatment also suggested that the microwave irradiation changed the surface structure of nutshell-AC (Table 1).

Representative SEM images of the activated carbon supports and catalysts are shown in Fig. 3. The nutshell-AC and coconut-AC carbon supports had a distinct porous structure while coal-AC carbon showed a compact structure. Many of the macropores of $\mathrm{Ru} /$ nutshell-AC were filled with agglomerated ruthenium particles with diameters above $50 \mathrm{~nm}$. The particle sizes of the ruthenium crystallites of $\mathrm{Ru} /$ coconut-AC were approximate $10 \mathrm{~nm}$, and some small particles were incorporated into the macropores of coconut-AC carbon. The sizes of most ruthenium particles in $\mathrm{Ru} / \mathrm{coal}-\mathrm{AC}$ prepared by microwave heating were in the range of $10 \mathrm{~nm}$ or less. These were well dispersed on the surface of the coal-AC carbon support. $\mathrm{Ru} / \mathrm{coal}-\mathrm{AC}$ prepared by conventional heating showed some ruthenium particles larger than $50 \mathrm{~nm}$. It also showed many smaller clusters of about $20 \mathrm{~nm}$ in diameter. It was obvious that the metal dispersion of the microwave heated Ru/Coal-AC catalyst was higher than that of the conventionally heated $\mathrm{Ru} /$ Coal-AC catalyst.

\subsection{Influence of heating method on catalyst activity}

The effect of the heating method on the catalytic activity of the $\mathrm{Ru} / \mathrm{Coal}-\mathrm{AC}$ catalyst was studied. The experimental results are shown in Fig. 4. For the catalysts prepared using microwave

Table 1

Characterization of the activated carbon supports and catalysts prepared by microwave heating.

\begin{tabular}{|c|c|c|c|c|c|c|c|}
\hline \multirow{2}{*}{ Samples } & \multirow{2}{*}{ Size (mesh) } & \multirow{2}{*}{$\mathrm{pH} \mathrm{PZC}_{\mathrm{P}}$} & \multirow{2}{*}{ Ash (\%) } & \multirow{2}{*}{$\begin{array}{c}\text { Surface area } \\
\left(\mathrm{m}^{2} / \mathrm{g}\right)\end{array}$} & \multicolumn{2}{|c|}{ Pore volume $\left(\mathrm{cm}^{3} / \mathrm{g}\right)$} & \multirow{2}{*}{$\begin{array}{c}\text { Basic groups } \\
(\mu \mathrm{Eq} / \mathrm{g})\end{array}$} \\
\hline & & & & & Mesopore & Macropore & \\
\hline Nutshell-AC & $9-12$ & 3.73 & 1.0 & 761.8 & 0.11 & 0.23 & 1523 \\
\hline Nutshell-AC * & - & - & - & 850.3 & 0.10 & 0.23 & 880 \\
\hline $\mathrm{Ru} /$ nutshell-AC & - & - & - & 823.6 & 0.07 & 0.16 & 856 \\
\hline Coconut-AC & $8-12$ & 3.60 & 0.95 & 896.3 & 0.09 & 0.10 & 560 \\
\hline $\mathrm{Ru} /$ coconut-AC & - & - & - & 873.3 & 0.07 & 0.06 & 508 \\
\hline Coal-AC & $6-10$ & 3.91 & 7.8 & 968.9 & 0.02 & 0.03 & 554 \\
\hline$\underline{\mathrm{Ru} / \mathrm{coal}-\mathrm{AC}}$ & - & - & - & 945.2 & 0.02 & 0.02 & 501 \\
\hline
\end{tabular}

* It was irradiated with the same conditions as microwave heated catalyst but without ruthenium impregnation.

Table 2

Chemical composition of different activated carbon ashes.

\begin{tabular}{|c|c|c|c|c|c|c|c|c|c|c|c|}
\hline \multirow{2}{*}{ Sample } & \multicolumn{11}{|c|}{ Chemical composition (\%) } \\
\hline & $\mathrm{Fe}_{2} \mathrm{O}_{3}$ & $\mathrm{MnO}_{2}$ & $\mathrm{TiO}_{2}$ & $\mathrm{CaO}$ & $\mathrm{K}_{2} \mathrm{O}$ & $\mathrm{SO}_{3}$ & $\mathrm{P}_{2} \mathrm{O}_{5}$ & $\mathrm{SiO}_{2}$ & $\mathrm{Al}_{2} \mathrm{O}_{3}$ & $\mathrm{MgO}$ & $\mathrm{Na}_{2} \mathrm{O}$ \\
\hline Nutshell-AC & 5.99 & 0.04 & 0.72 & 4.78 & 5.32 & 5.16 & 0.65 & 57.34 & 15.82 & 2.54 & 1.64 \\
\hline Coconut-AC & 10.60 & 0.09 & 0.64 & 1.55 & 6.04 & 1.77 & 0.71 & 64.82 & 7.63 & 1.22 & 4.93 \\
\hline Coal-AC & 3.56 & 0.02 & 0.68 & 0.60 & 0.32 & 0.25 & 0.32 & 71.70 & 20.96 & 0.19 & 1.40 \\
\hline
\end{tabular}



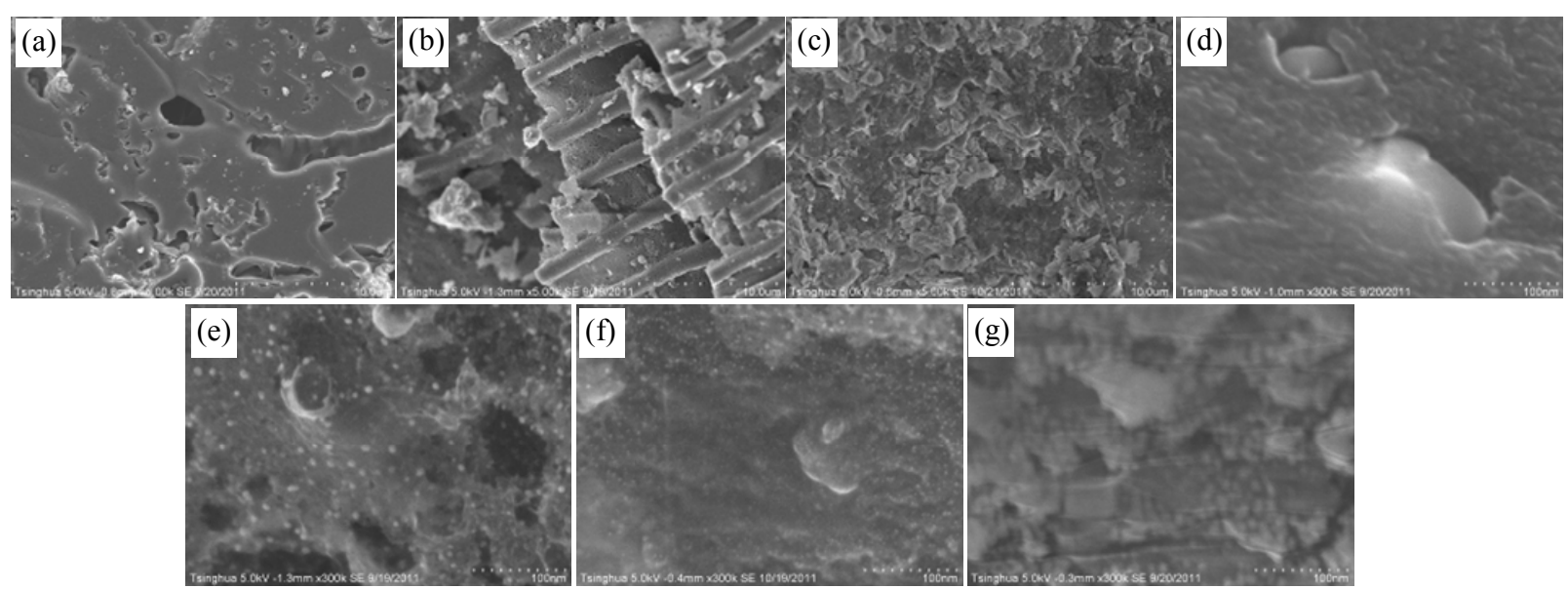

Fig. 3. SEM images of nutshell-AC (a), coconut-AC (b), coal-AC (c), Ru/nutshell-AC (d), Ru/coconut-AC (e), and Ru/coal-AC prepared by microwave irradiation (f) and conventional calcination (g).

irradiation, the best catalyst was obtained with the microwave irradiation power of $300 \mathrm{~W}$ (Fig. 4(a)). For the catalysts prepared using conventional calcination, the best catalyst was obtained with the calcination temperature of $500{ }^{\circ} \mathrm{C}$ (Fig. 4(b)). This indicated that heating was necessary for the development of catalyst activity but excessive heating caused a decrease in catalyst activity. Generally, heating at a high temperature causes the growth of metal particles on the catalyst surface and even causes their aggregation. This will decrease the metal dispersion of the catalyst and finally result in the decrease of catalyst activity [24-26].

From Fig. 4, it was also seen that the microwave heated $\mathrm{Ru} /$ Coal-AC catalyst prepared at $300 \mathrm{~W}$ was more active than the conventionally heated $\mathrm{Ru} / \mathrm{Coal}-\mathrm{AC}$ catalyst prepared at 500 ${ }^{\circ} \mathrm{C}$. Berry et al. [26] analyzed the XRD patterns of microwave and conventionally heated catalysts, and attributed the catalytic performance enhancement by microwave heating to the

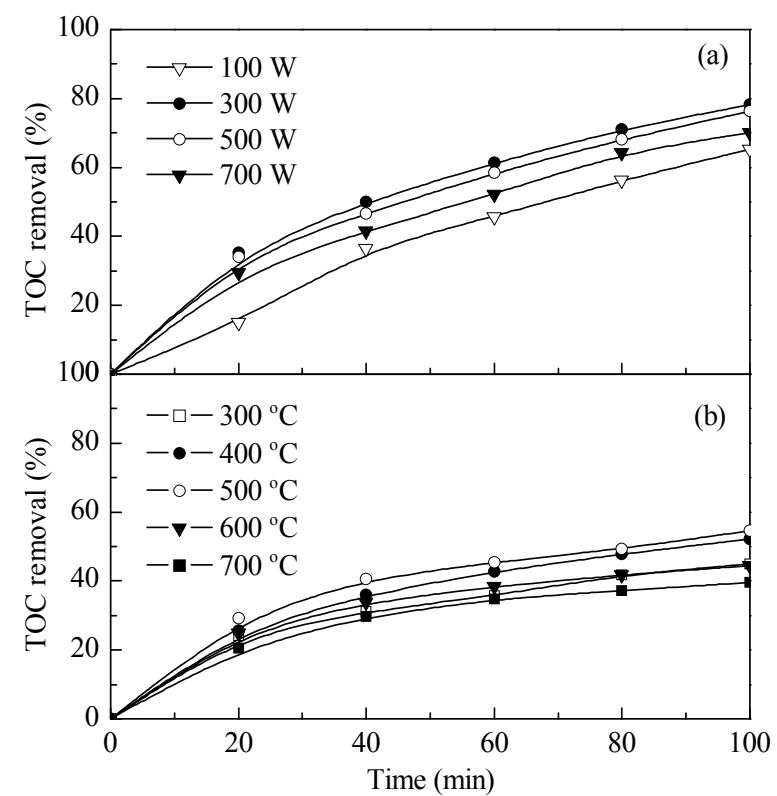

Fig. 4. TOC removal in the catalytic ozonation of DMP over the catalysts prepared by microwave irradiation at different powers (a) and by conventional calcination at different temperatures (b). change of the metal particle size. Although the particle size of both catalysts could not be calculated from their XRD patterns, their SEM images clearly showed that the microwave heated $\mathrm{Ru} /$ Coal-AC catalyst had smaller metal particles and a higher metal dispersion than the conventionally heated $\mathrm{Ru} /$ Coal-AC catalyst. This supported the above conclusion that the increase of calcination temperature and microwave irradiation power resulted in the decrease of catalyst activity because of the increase of the metal particle size.

\subsection{Effect of support type on catalyst activity}

Figure 5 shows TOC removal after 100 min DMP ozonation in the presence of the different activated carbon supports and catalysts. At the same reaction conditions, TOC removal was only $29 \%$ with ozonation alone (not shown in Fig. 5). All the carbon supports and catalysts increased the TOC removal rate in the catalytic DMP ozonation. The activity order was $\mathrm{Ru} /$ coal- $\mathrm{AC}>$ nutshell- $\mathrm{AC}>\mathrm{Ru} /$ nutshell- $\mathrm{AC}>\mathrm{Ru} /$ coconut- $\mathrm{AC} \approx$ coal-AC $>$ coconut-AC. In the catalytic ozonation of DMP with the activated carbon supports, TOC was removed by both the

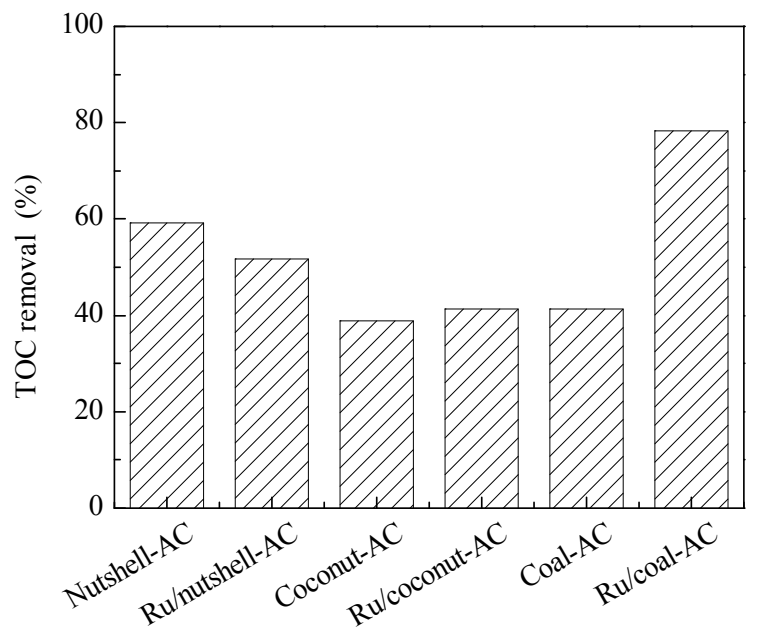

Fig. 5. TOC removal after 100 min DMP ozonation over different activated carbon supports and Ru-based catalysts. 
catalytic activity to mineralize the organic matter and the adsorption of the organic compounds on the activated carbon. As discussed in the Ref. [27], it is hard to determine the separate contributions of these two effects to TOC removal because many intermediates are produced during the catalytic ozonation of the parent compounds. It is very difficult to measure the concentration of the intermediates and calculate their adsorbed amounts. By considering that nutshell-AC carbon enhanced TOC removal the most and yet had the smallest surface area among all the carbons, it can be inferred that the adsorption of the organic compounds on carbon was not the main factor determining TOC removal activity. Rivera-Utrilla et al. [27] reported that the surface basic groups on activated carbon were mostly responsible for the formation of the highly oxidative species, which improved catalytic activity. He also concluded that macroporosity in the carbon support enhanced the ozonation by reducing diffusion problems and therefore giving access of the ozone to the active centers of the carbon. In this study, among the activated carbon supports, nuthshell-AC carbon had the highest macropore volume and concentration of surface basic groups (Table 1), and it improved catalytic ozonation the most. From these data, it can be inferred that the surface basic groups and macropores of the activated carbon played an important role for the catalytic activity of the catalyst (mineralization effect) in the catalytic ozonation of DMP.

TOC removal in the catalytic ozonation of DMP with $\mathrm{Ru} /$ coal-AC was $49 \%$ and $37 \%$ higher than those with ozonation alone and catalytic ozonation with coal-AC, respectively. When the reaction was carried out with $2 \mathrm{~g} / \mathrm{L}$ of $\mathrm{Ru} / \mathrm{Coal}-\mathrm{AC}$ catalyst and $400 \mathrm{ml} / \mathrm{min}$ of pure oxygen, the TOC removal was less than $20 \%$ after 100 min reaction. So the adsorption on the catalysts and air stripping had little effect on the removal of DMP. Ref. [11] also reported that adsorption on the catalyst and air stripping had a small effect on the removal of DMP with the catalyst dosage of $2 \mathrm{~g} / \mathrm{L}$ and oxygen flow rate of $300 \mathrm{ml} / \mathrm{min}$. As it is well accepted that the reaction between ozone and DMP is fast $[11,14]$ and the hydroxyl radical produced during catalytic ozonation is not selective, it can be concluded that the intermediates in the catalytic ozonation of DMP with coal-AC and $\mathrm{Ru} /$ coal-AC were the same. Since the TOC removal rate in the catalytic ozonation of DMP in the presence of $\mathrm{Ru} /$ coal-AC was much higher than that in the presence of coal-AC, it was inferred that $\mathrm{Ru} / \mathrm{coal}-\mathrm{AC}$ possessed excellent activity and the mineralization of organic compounds with $\mathrm{Ru} /$ coal-AC played an important role in TOC removal.

Although it is difficult to interpret clearly why the $\mathrm{Ru} /$ coconut-AC and $\mathrm{Ru} /$ nutshell-AC catalysts were less active than $\mathrm{Ru} / \mathrm{Coal}-\mathrm{AC}$ in the catalytic zonation of DMP, the catalyst characterization gave some clues. First, the SEM images of $\mathrm{Ru} /$ coconut-AC and $\mathrm{Ru} /$ nutshell-AC showed that some ruthenium particles were dispersed in the macropores of the activated carbon. The occupation of the macropores by metal particles would result in a reduced adsorption of organic compounds and also increase the mass transfer resistance in the pores. This would decrease the chance that the organic compounds would contact the ruthenium particles in the pores. At the same time, the activated carbon would also cover the ru- thenium particles in the pores and thus decrease the contact between reactants and the ruthenium particles. All these effects caused the reduction of catalyst activity. Second, the surface area analysis indicated that the surface structure of nutshell-AC carbon was changed to some extent when it was treated by microwave irradiation. If the changes were at the active centers of the activated carbon such as the surface basic groups, the microwave irradiation would result in a decline of catalytic activity. This was perhaps the reason why $\mathrm{Ru} /$ nutshell-AC had a lower activity than the nutshell-AC carbon support. Finally, that the metal dispersions of $\mathrm{Ru} /$ coconut-Ac and $\mathrm{Ru} /$ nutshell-AC were lower than that of $\mathrm{Ru} / \mathrm{Coal}-\mathrm{AC}$ was also a reason for their different catalytic activities.

\section{Conclusions}

Ruthenium catalysts supported on activated carbon supports possessed excellent activity in the catalytic ozonation of DMP and they effectively enhanced the TOC removal rate. The pore size distribution and surface functional groups present on the activated carbon support greatly influenced catalyst activity. Macropores enhanced the mass transfer of the reactants and enabled them to contact the active phases on the inner surface of the activated carbon more easily. This would increase the catalytic ozonation reaction rate. After loading of the noble metal, metal particles can diffuse into the macropores and prevent reactants from contacting the metal particles and active phase on the inner surface of the activated carbon. This would decrease the catalytic ozonation reaction rate. As compared to conventional heating, microwave heating enhanced the metal dispersion of $\mathrm{Ru} / \mathrm{coal}-\mathrm{AC}$ and hence increased its activity. However, microwave heating decrease the activity of $\mathrm{Ru} /$ nutshell-AC because it deteriorated the active phases on the surface of the activated carbon support.

\section{References}

[1] Kasprzyk-Hordern B, Ziolek M, Nawrocki J. Appl Catal B, 2003, 46: 639

[2] Lü A H, Hu Ch, Nie Y L, Qu J H. Appl Catal B, 2010, 100: 62

[3] Dong Y M, Yang H X, He K, Song Sh Q, Zhang A M. Appl Catal B, 2009, 85: 155

[4] Kasprzyk-Hordern B, Raczyk-Stanisławiak U, Swietlik J, Nawrocki J. Appl Catal B, 2006, 62: 345

[5] Orge C A, Orfao J J M, Pereira M F R, de Farias A M D, Neto R C R, Fraga M A. Appl Catal B, 2011, 103: 190

[6] Huang Y, Li K X, Yan L Sh, Dai Y H, Huang Zh M, Xue K P, Guo H Q, Xiong J J. Chin J Catal (黄燕, 李可心, 颜流水, 戴玉华, 黄智敏, 薛 昆鹏, 郭会琴, 熊晶晶. 催化学报), 2012, 33: 308

[7] Yang H W, Yang Sh X, Wu L, Liu W J. Catal Commun, 2001, 15: 99

[8] Zhao J H, Liu Zh Y. Chin J Catal (赵江红, 刘振宇. 催化学报), 2005, 26: 143

[9] Dong Y M, Jiang P P, Zhang A M. Chin J Inorg Chem, 2009, 25: 1595

[10] Yalfani M S, Contreras S, Llorca J, Medina F. Appl Catal B, 2011, 107: 9

[11] Wang J B, Zhou Y R, Zhu W P, He X W. J Hazard Mater, 2009, 166: 502

[12] Huang R H, Yan H H, Li L Sh, Deng D Y, Shu Y H, Zhang Q Y. Appl Catal B, 2011, 106: 264 


\title{
Graphical Abstract
}

Chin. J. Catal., 2013, 34: 313-321 doi: 10.1016/S1872-2067(11)60479-8

Relationship between the structure and activity of ruthenium catalysts in the catalytic ozonation of dimethyl phthalate

WANG Jianbing*, WANG Can, YANG Chunli, WANG Guoqing, ZHU Wanpeng

China University of Mining and Technology, Beijing Campus; Tsinghua University

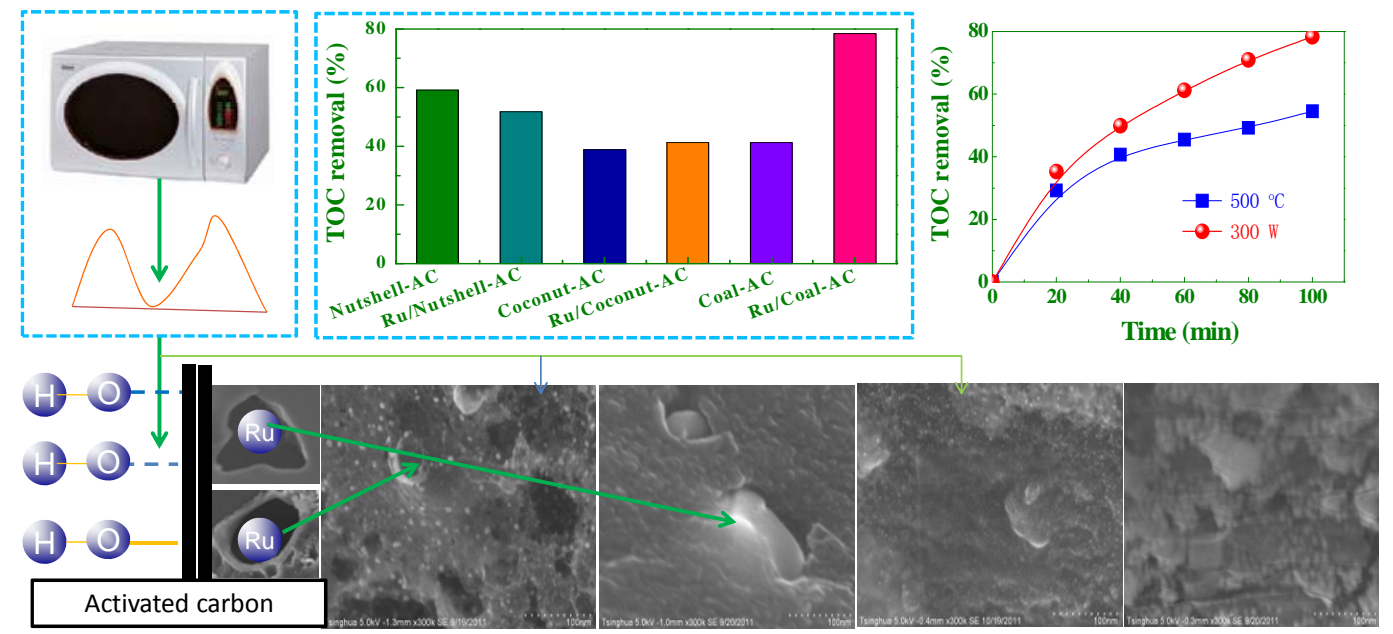

The surface structure of the activated carbon (AC) support influenced the activity of Ru/AC catalysts in dimethyl phthalate ozonation. Microwave heating during catalyst preparation changed the catalyst activity by a modification of its surface structure.

[13] Long L P, Zhao J G, Yang L X, Fu M L,Wu J L, Huang B Ch, Ye D Q. Chin J Catal (龙丽萍, 赵建国, 杨利娴, 付名利, 吴军良, 黄碧纯, 叶代启. 催化学报), 2011, 32: 904

[14] Zhou Y R, Zhu W P, Liu F D, Wang J B, Yang Sh X. Chemosphere, 2007, 66: 145

[15] Faria P C C, Orfao J J M, Pereira M F R. Catal Commun, 2008, 9: 2121

[16] Liu Zh Q, Ma J, Cui Y H, Zhang B P. Appl Catal B, 2009, 92: 301

[17] Dong Y M, Yang H X, He K, Wu X, Zhang A M. Appl Catal B, 2008, 82: 163

[18] Pines D S, Reckhow D A. Ozone: Sci Eng, 2003, 25: 25

[19] Faria P C C, Orfao J J M, Pereira M F M. Appl Catal B, 2008, 79: 237
[20] Zhang T, Li Ch J, Ma J, Tian H, Qiang Zh M. Appl Catal B, 2008, 82: 131

[21] Boehm H P. Adv Catal, 1966, 16: 179

[22] Salame I I, Bandosz T J.J Colloid Interf Sci, 2001, 240: 252

[23] Bader H, Hoigne J. Water Res, 1981, 15: 449

[24] Hosokawa S, Kanai H, Utani K, Taniguchi Y-i, Saito Y, Imamura S. Appl Catal B, 2003, 45: 181

[25] Barbier J Jr, Delanoë F, Jabouille F, Duprez D, Blanchard G, Isnard P. J Catal, 1998, 177: 378

[26] Berry F J, Smart L E, Prasad P S S, Lingaiah N, Rao P K. Appl Catal A, 2000, 204: 191

[27] Rivera-Utrilla J, Sanchez-Polo M. Appl Catal B, 2002, 39: 319

\section{催化臭氧氧化降解邻苯二甲酸二甲酯中催化剂构效关系}

\author{
王建兵 ${ }^{\mathrm{a},}{ }^{*}$ ，王 灿 ${ }^{\mathrm{a}}$ ，杨春丽 ${ }^{\mathrm{a}}$ ，王国庆 ${ }^{\mathrm{a}}$, 祝万鹏 ${ }^{\mathrm{b}}$ \\ ${ }^{\mathrm{a}}$ 中国矿业大学 (北京) 化学与环境工程学院, 北京 100083

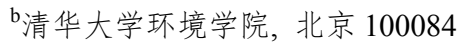

摘要: 采用传统焙烧和微波辐射制备了不同活性炭 (AC) 负载 Ru催化剂, 并用于催化臭氧氧化降解邻苯二甲酸二甲酯 (DMP) 反应 中, 探讨了催化剂的构效关系. 结果表明, 所有 $\mathrm{AC}$ 和催化剂均能提高臭氧氧化 DMP 过程中 TOC (总有机碳) 去除率, 其活性顺序为 $\mathrm{Ru} /$ coal-AC $>$ nutshell-AC $>\mathrm{Ru} /$ nutshell- $\mathrm{AC}>\mathrm{Ru} /$ coconut- $\mathrm{AC} \approx$ coal-AC $>$ coconut-AC. 负载的 $\mathrm{Ru}$ 颗粒扩散到 $\mathrm{AC}$ 大孔, 增加了反应 的传质阻力, 使得反应物与 $\mathrm{AC}$ 内表面的活性位和金属 $\mathrm{Ru}$ 的接触机会减少, 这是 Ru/nutshell-AC 和 Ru/coconut- $\mathrm{AC}$ 活性低于 $\mathrm{Ru} / \mathrm{coal}-\mathrm{AC}$ 的一个原因; 催化剂表面 Ru 分散度也是导致其活性差别的原因之一. 微波加热引起 nutshell-AC 表面活性官能团发生 变化, 从而导致其负载的 $\mathrm{Ru}$ 催化活性降低. 相对于传统焙烧,微波辐射热处理能够提高 coal- $\mathrm{AC}$ 表面 Ru的分散度, 从而提高催化剂 活性.

关键词：催化臭氧氧化; 邻苯二甲酸二甲酯; 钉; 活性炭 
收稿日期: 2012-08-31. 接受日期: 2012-10-30. 出版日期: 2013-02-20.

*通讯联系人. 电话/传真: (010)62339087; 电子信箱: wangjb@cumtb.edu.cn

基金来源: 国家自然科学基金 (20907072).

本文的英文电子版由Elsevier出版社在ScienceDirect上出版(http://www.sciencedirect.com/science/journal/18722067)

\section{1. 前言}

近年来, 内分泌干扰物对饮用水造成了严重的污染; 这类物质在水中的浓度一般较低, 大多难以生物降解,传 统水处理技术也难以有效去除. 臭氧氧化技术可有效去 除这些有机污染物, 但矿化效果不高, 不易将其彻底氧化 为 $\mathrm{CO}_{2}$ 和 $\mathrm{H}_{2} \mathrm{O}$, 而催化臭氧氧化法则具有更高的矿化效 果 (即更高的 TOC (总有机碳) 去除率). 目前催化臭氧氧 化 (尤其是非均相催化臭氧氧化) 是臭氧氧化领域的研 究热点 ${ }^{[1]}$; 已报道可用的催化剂包括金属氧化物 (如 $\mathrm{Fe}_{2} \mathrm{O}_{3}, \mathrm{MnO}_{2}, \mathrm{Al}_{2} \mathrm{O}_{3}, \mathrm{Ce}_{2} \mathrm{O}_{3}, \mathrm{WO}_{3}-\mathrm{TiO}_{2}$ 和 $\left.\mathrm{Ce}_{x} \mathrm{Zr}_{1-x} \mathrm{O}_{2}\right)^{[2 \sim 7]}$ 、 负载金属或金属氧化物 (如 $\mathrm{Fe} / \mathrm{AC}, \mathrm{Cu} / \mathrm{Al}_{2} \mathrm{O}_{3}, \mathrm{Ru} / \mathrm{AC}$, $\mathrm{Fe} / \mathrm{SBA}-15, \mathrm{MnO}_{2} / \mathrm{Al}_{2} \mathrm{O}_{3}$ 和 $\left.\mathrm{RuO}_{2} / \mathrm{Al}_{2} \mathrm{O}_{3}\right)^{[8-14]}$ 和一些多孔 材料 (如活性炭、碳纳米管和沸石) ${ }^{[15 \sim 17]}$. 在负载型催化 剂中, 活性炭 $(A C)$ 载 $R u$ 被认为是非常有前途的, 但有关 其构效关系的研究较少. 一般认为, 在催化臭氧氧化过 程中, 臭氧会被催化剂表面的氧化/还原态金属 ${ }^{[18]} 、$ Lewis 酸碱中心 ${ }^{[2,19]}$ 、非离解羟基 ${ }^{[20]}$ 等位点吸附后分解产生自 由基, 与水中有机物发生反应、或催化剂表面的分解产 物与催化剂表面吸附有机物进行反应. 目前报道的催化 臭氧氧化机理均基于大量假设, 存在较多的不确定性,无 法清楚阐述催化剂表面非均相反应的微观机理, 因而构 效关系的研究对于开发高效催化剂具有非常重要的意 义.

本文采用传统焙烧和微波辐射方法制备了不同 $\mathrm{AC}$ 载 $\mathrm{Ru}$ 催化剂, 考察它们催化臭氧氧化降解水中邻苯二甲 酸二甲酯 (DMP) 的活性, 探讨制备方法对催化剂结构的 影响以及催化剂的构效关系.

\section{2. 实验部分}

\section{1. 催化剂的制备}

催化剂载体采用三种颗粒活性炭, 分别是果壳活性 炭 (nutshell-AC)、椰壳活性炭 (coconut-AC) 和煤质活性 炭 (coal-AC), 均购自北京远大集成活性炭有限公司. 使 用前,活性炭用去离子水充分清洗并干燥.

采用等体积浸渍法制备催化剂. 将活性炭在 $\mathrm{RuCl}_{3}$ (AR) 溶液中浸渍 $24 \mathrm{~h}$, 然后于 $100^{\circ} \mathrm{C}$ 干燥, 再在图 1 所示 的微波加热反应器 (三洋公司, EM-202MS1 型) 中辐射 3 $\min$ 得到成品催化剂. 每次将 $20 \mathrm{~g}$ 催化剂加到石英管 (内 径为 $32 \mathrm{~mm}$, 高 $380 \mathrm{~mm}$ ) 中, 石英管底部距微波反应器底 部为 $20 \mathrm{~mm}$, 微波炉腔体高 $300 \mathrm{~mm}$, 催化剂床层全部位 于微波炉微波辐射腔体内, 冷凝回流装置确保微波辐射 产生的气体全部凝结为液态.

为了研究不同热处理方法对催化剂结构和活性的 影响, 将一部分浸渍后的 Ru/coal-AC 催化剂置于马弗炉 中, 分别在 $300,400,500,600$ 和 $700^{\circ} \mathrm{C}$ 焙烧 $3 \mathrm{~h}$, 制得催化 剂.

所有催化剂 $\mathrm{Ru}$ 理论负载量为 $0.5 \%$. 采用日本 Shimadzu 公司的 XRF1700 型 X 射线荧光光谱仪分析样品 中实际 $\mathrm{Ru}$ 含量,表明两者相差不超过 $5 \%$.

\section{2. 催化剂的评价}

DMP 降解反应的装置参见文献[14]. 反应前, 先向 反应器中加入 $1000 \mathrm{ml}$ 的 DMP 溶液 $(5 \mathrm{mg} / \mathrm{L}$, 初始 $\mathrm{pH}$ 值 为 6.6), 催化臭氧氧化降解 DMP 的实验中还要加入 $2 \mathrm{~g} / \mathrm{L}$ 的活性炭或 $\mathrm{Ru} / \mathrm{AC}$ 催化剂, 然后通入 $400 \mathrm{ml} / \mathrm{min}$ 的 $\mathrm{O}_{3}-\mathrm{O}_{2}$ 气, 进气压力为 $0.04 \mathrm{MPa}$, 臭氧产量为 $195 \mathrm{mg} / \mathrm{h}$. 反应过 程中通过控温仪保证反应器中温度为 $(15 \pm 0.5)^{\circ} \mathrm{C}$, 控温 仪的构造见文献 [14]. 在确定的时间间隔取样, 采用 NPOC 的分析方法分析溶液的 TOC.

\section{3. 催化剂的表征和分析方法}

采用美国 Micromeritics 公司 ASAP 2010 型比表面 积分析仪测量样品的比表面积. $\mathrm{AC}$ 的介孔体积和大孔 体积采用压录仪 (美国 Quantachrome 公司, Autoscan 33) 分析. 利用日本理学 $\mathrm{D} / \mathrm{max}$-IIIA 型 $\mathrm{X}$ 射线粉末衍射 (XRD) 仪分析催化剂的晶体结构, $\mathrm{Cu}$ 靶 $K_{\alpha}$ 射线 $(\lambda=$ $1.5418 \mathrm{~nm}$ ), 管电压 $40 \mathrm{kV}$, 管电流 $100 \mathrm{~mA}$, 扫描范围 $2 \theta=$ $10^{\circ} \sim 80^{\circ}$, 扫描速率 $6^{\circ} / \mathrm{s}$. 催化剂的表面形貌和 $\mathrm{Ru}$ 粒子尺 寸采用日本 Hitachi 公司的 S-5500 型场发射扫描电镜 (SEM) 分析, 并带有背散射电子检测器, 根据背散射电子 成像区域的亮度区分 Ru. 采用 Boehm 滴定法分析载体 表面的碱性基团 ${ }^{[21,22]}$. 根据碘量法分析臭氧浓度 ${ }^{[23]}$; TOC 检测采用 TOC 仪 (日本 Shimadzu 公司, TOC2Vwp) 测定.

\section{3. 结果与讨论}

\section{1. 催化剂的表征结果}


图 2 为活性炭 coal-AC 和两种方法制备的 $\mathrm{Ru} / \mathrm{coal}-\mathrm{AC}$ 样品的 XRD 谱. 由图可见, Ru/coal-AC 催化 剂在 $2 \theta=44.0^{\circ}$ 处出现一个微弱的金属 $\mathrm{Ru}$ 衍射峰. 这可 能是由于 $R u$ 负载量低或高度分散所致. 在热处理过程 中, $\mathrm{AC}$ 具有还原作用, 可防止 $\mathrm{Ru}$ 被氧化.

表 1 和表 2 为不同 $\mathrm{AC}$ 及其负载 $\mathrm{Ru}$ 催化剂的表征结 果. 可以看出, 各样品的比表面积均较大, 为 700 1000 $\mathrm{m}^{2} / \mathrm{g}$. 一般来说, $\mathrm{AC}$ 负载金属后, 金属颗粒会扩散到 $\mathrm{AC}$ 的孔隙内，从而导致比表面积变小. 本文中 $\mathrm{Ru} /$ coconut-AC 和 $\mathrm{Ru} /$ coal-AC 的比表面积和大孔体积均 小于其载体, 但 Ru/nutshell-AC 的比表面积却大于 nutshell-AC. 这说明微波辐射处理对于 nutshell-AC 存在一 定的扩孔作用,也意味着微波辐射导致 nutshell-AC 表面 结构发生了变化; Ru/nutshell-AC 表面的碱性基团数量 小于 nutshell-AC, 进一步说明微波辐射导致 nutshell-AC 表面化学结构发生了变化. 将经过微波辐射热处理的 nutshell-AC 与未经微波辐射热处理的样品对比, 也可以 看出微波辐射使得 nutshell-AC 的表面化学结构发生了 变化.

图 3 为 $\mathrm{AC}$ 及其负载 $\mathrm{Ru}$ 催化剂的 SEM 照片. 可以看 出, 在较低放大倍数下, coconut-AC 和 nutshell-AC 呈现 出明显的多孔纤维结构, 而 coal-AC 的结构较紧凑; $\mathrm{Ru} / \mathrm{nutshell}-\mathrm{AC}$ 的大孔被约为 $50 \mathrm{~nm}$ 的 Ru 颗粒占据, 而 $\mathrm{Ru} /$ coconut- $\mathrm{AC}$ 表面的 $\mathrm{Ru}$ 颗粒尺寸约为 $10 \mathrm{~nm}$, 一些细粒 子扩散到载体大孔中. 还可以看出, 微波辐射制备的 $\mathrm{Ru} / \mathrm{coal}-\mathrm{AC}$ 的 $\mathrm{Ru}$ 颗粒尺寸约为 $10 \mathrm{~nm}$, 有的更小, $\mathrm{Ru}$ 分 散度较高; 而传统焙烧制备的 Ru/coal-AC 中 Ru颗粒尺 寸大于 $50 \mathrm{~nm}$, 还可观察到大量的 $20 \mathrm{~nm}$ 左右的颗粒聚集 在一起. 由此可见, 微波辐射制备的 Ru/coal-AC 催化剂 具有更小的 $R u$ 粒子和更高的 $R u$ 分散度.

\section{2. 热处理对催化剂活性的影响}

研究了制备过程中热处理对 Ru/coal-AC 催化剂活 性的影响, 结果如图 4 所示. 可以看出, 当微波辐射功率 为 $300 \mathrm{~W}$ 时, 催化剂的活性最高; 对于传统焙烧而制得的 $\mathrm{Ru} / \mathrm{AC}$ 催化剂, 焙烧温度为 $500^{\circ} \mathrm{C}$ 时, 催化剂的活性最 高. 可见, 适度加热可提高催化剂活性. 一般说来, 高温加 热容易导致催化剂表面负载的金属颗粒长大甚至团聚, 而降低其分散度,使得其活性降低 ${ }^{[24-26]}$.

比较而言, 微波功率为 $300 \mathrm{~W}$ 时制备的催化剂催化 臭氧氧化活性比 $500^{\circ} \mathrm{C}$ 焙烧而制得的催化剂更高. Berry 等 ${ }^{[26]}$ 比较了微波辐射和传统焙烧制备催化剂的 XRD 谱, 认为两者之间的粒子尺寸差别是其活性不同的重要原
因. 本文 SEM 结果显示, 微波辐射制备的催化剂分散度 更高, 金属颗粒尺寸更小. 因此, $\mathrm{Ru} / \mathrm{coal}-\mathrm{AC}$ 在臭氧氧化 DMP 反应中表现出更高的催化活性, 而焙烧温度和辐射 功率的增加导致催化剂活性降低, 则主要是由于 $\mathrm{Ru}$ 粒子 变大所致.

\section{3. 载体种类对催化剂活性的影响}

图 5 给出了不同 $\mathrm{AC}$ 及其负载 $\mathrm{Ru}$ 催化剂(微波制备) 催化臭氧氧化 DMP 反应 $100 \mathrm{~min}$ 后 TOC 去除率. 相同条 件下, 不加催化剂或 $\mathrm{AC}$ 时, 臭氧氧化 TOC 去除率为 $29 \%$ (未给出), 而各 AC 和相应催化剂的加入均可有效提 高臭氧氧化 TOC 的去除率, 它们的活性顺序为: $\mathrm{Ru} /$ coal-AC $>$ nutshell-AC $>$ Ru/nutshell-AC $>$ $\mathrm{Ru} /$ coconut-AC $\approx$ coal-AC $>$ coconut-AC. AC 催化臭氧氧 化过程中, TOC 的去除是通过催化臭氧氧化对有机物矿 化作用和 $\mathrm{AC}$ 对有机物的吸附作用而达到的, 正如文献 [27]中指出, 很难定量给出这两种作用对 TOC 去除的贡 献, 因为母体化合物降解生成的中间产物较多, 目前很难 检测出全部中间产物和确定 $\mathrm{AC}$ 对它们的吸附量. 尽管 nutshell-AC 的比表面积最低, 但其对 TOC 去除率高于其 他 AC. 可见, 在 $\mathrm{AC}$ 催化臭氧氧化中,有机物表面吸附并 不是 TOC 去除的主要途径. Rivera-Utrilla 等 ${ }^{[27]}$ 认为, AC 表面的碱性基团是导致催化臭氧氧化过程中高活性氧 化剂 (例如羟基自由基)生成的主要官能团, 且 $\mathrm{AC}$ 的大 孔中扩散阻力较小, 有利于臭氧和反应物扩散到 $\mathrm{AC}$ 孔 隙中进行反应, 从而有利于臭氧氧化作用. 相对于其它 $\mathrm{AC}$, nutshell-AC 具有最高的碱性基团浓度和最大的大孔 体积, 且其去除 TOC 的效果最好. 因此可推断, 在本文条 件下 $\mathrm{AC}$ 催化臭氧氧化 $\mathrm{DMP}$ 过程中, $\mathrm{AC}$ 的碱性基团和 大孔体积均起着重要的作用.

相对于单独臭氧氧化, Ru/coal-AC催化臭氧氧化降 解 DMP, 反应 $100 \mathrm{~min}$ 后 TOC 去除率提高了 $49 \%$; 而相 对于 coal-AC 催化臭氧氧化, TOC 去除率则提高了 $37 \%$. 当向反应器中投加 $2 \mathrm{~g} / \mathrm{L}$ 的 $\mathrm{Ru} / \mathrm{coal}-\mathrm{AC}$ 催化剂, 通入 400 $\mathrm{ml} / \mathrm{min}$ 的 $\mathrm{O}_{2}$, 反应 $100 \mathrm{~min}$ 后 TOC 去除率不超过 $20 \%$, 催 化剂的吸附和气体吹脱对 DMP 的去除效果较低. Wang 等 ${ }^{[1]}$ 也发现, 当投加 $2 \mathrm{~g} / \mathrm{L}$ 催化剂、 $300 \mathrm{ml} / \mathrm{min}$ 的 $\mathrm{O}_{2}$ 时反 应 $100 \mathrm{~min}$, 吸附和吹脱对 DMP 的去除率较低. 由于臭氧 与 DMP 之间的反应为快速反应 ${ }^{[1,14]}$, 同时普遍认为催化 臭氧氧化过程中生成的自由基对有机物的氧化没有选 择性, 因而可认为, coal-AC 和 Ru/coal-AC 催化臭氧氧化 降解 DMP 的中间产物种类基本相同, 但后者的 TOC 去 除率更高. 可见, $\mathrm{Ru} / \mathrm{coal}-\mathrm{AC}$ 具有良好的催化氧化活性, 
它的矿化作用对 TOC 的去除起到了重要作用.

根据本文的结果, 全面阐述 $\mathrm{Ru} /$ coconut-AC 和 $\mathrm{Ru} /$ nutshell-AC 的活性比 $\mathrm{Ru} / \mathrm{coal}-\mathrm{AC}$ 低的原因还非常困 难, 但可在一定程度上解释这种活性差别. 首先, SEM 结 果显示, $\mathrm{Ru} /$ coconut-AC 和 $\mathrm{Ru} /$ nutshell-AC 中一些 $\mathrm{Ru}$ 颗 粒扩散到载体大孔中, 使得 $\mathrm{AC}$ 对有机物的吸附减少, 还 会增加孔中的传质阻力, 减少臭氧和有机物接触到活性 炭内表面活性位的机会; 同时 $\mathrm{AC}$ 也对金属 $\mathrm{Ru}$ 产生了一 种遮盖作用, 从而降低了反应物接触金属 $\mathrm{Ru}$ 的机会, 使 得催化剂的活性降低. 其次, 微波辐射使得 nutshell-AC 表面结构发生了较大变化, 如果这种变化恰好发生在催 化剂的活性基团, 使之发生受热分解 (例如碱性基团受 热分解), 必然也会导致催化剂活性的降低. 最后,
$\mathrm{Ru} /$ coconut-AC 和 $\mathrm{Ru} /$ nutshell-AC 表面金属分散度低于 $\mathrm{Ru} / \mathrm{coal}-\mathrm{AC}$ 也是它们活性存在差别的原因.

\section{4. 结论}

$\mathrm{Ru} / \mathrm{AC}$ 催化剂在臭氧氧化 DMP 反应中具有良好 的催化活性, 能够有效提高 TOC 去除率. AC 的孔径分 布和表面官能团对催化剂活性的影响较大. 大孔有利 于反应物扩散, 提高催化臭氧反应速率; 负载 $\mathrm{Ru}$ 后, 金属颗粒会扩散到大孔中, 降低了自身和 AC 内表面 活性位接触反应物的机会, 从而降低了反应速率. 相 对于传统的焙烧处理, 微波辐射处理能够提高 $R u$ 的 分散度, 从而提高其活性, 但是也可能会破坏 $\mathrm{AC}$ 表面 某些活性位, 导致其活性大幅降低.

\section{第二届国际生物质催化炼制大会(CatBior 2013)第一轮通知 时间: 2013 年 9 月 22 25 日 地点: 辽宁省大连市 承办单位: 中国科学院大连化学物理研究所}

\section{一、会议介绍}

国际生物质催化炼制大会 (International Congress on Catalysis for Biorefineries) 是在生物质催化转化技术蓬勃发展形 势下产生的国际性学术会议, 每两年召开一次, 由各大洲轮流 主办. 首届会议于 2011 年在西班牙召开, 第二届国际生物质 催化炼制大会 $\left(2^{\text {nd }}\right.$ International Congress on Catalysis for Biorefineries, http://catbior2013.dicp.ac.cn) 将于 2013 年 9 月 22 25 日在大连召开, 由中科院大连化学物理研究所承办.

本次大会旨在为全球生物质催化转化专家提供高水平的 学术交流平台, 展示生物质清洁高效催化转化技术的最新进 展, 并为来自世界各国的生物质转化工业界人士提供一个与 学界交流的契机, 从而推动生物质能源产业可持续发展.

\section{二、会议主题及征稿范围}

本次大会主题是生物质催化转化过程的基础和应用问题 研究, 征稿范围包括以下几个议题:

1. 纤维素、半纤维素、木质素及全生物质催化转化;

2. 碳水化合物及糖衍生物催化转化;

3. 油脂、微藻、脂肪及相关副产品的催化炼制;

4. 生物质热转化及生物油精制;

5. 其它生物质催化转化过程.

\section{三、投稿要求及日期}

大会组委会热诚欢迎从事生物质转化研究与技术开发的 专家、同行及在读研究生积极投稿并莅临本届盛会, 亦欢迎对 生物质转化有兴趣的企业参会或赞助. 会议采用在线投稿方 式, 关于详细论文摘要的格式要求, 请登录会议网站查看: http://catbior2013.dicp.ac.cn/dct/page/65558.

征稿截止日期为 2013 年 4 月 1 日, 通过评审的会议论文
将在《催化学报》及《Catalysis Today》上分别以专刊的形式 发表.

更多会议详情, 参见网站: http://catbior2013.dicp.ac.cn

四、会议承办单位及联系人

大会组委会主席: 张涛

中国科学院大连化学物理研究所

地址: 辽宁省大连市中山路 457 号

邮编: 116023

E-mail: taozhang@dicp.ac.cn

http://catbior2013.dicp.ac.cn

大会组委会副主席: 王爱琴

中国科学院大连化学物理研究所

地址: 辽宁省大连市中山路 457 号

邮编: 116023

电话: 0411-84379348

传真: 0411-84375940

E-mail: aqwang@dicp.ac.cn

大会组委会秘书: 李昌志 李宁

中国科学院大连化学物理研究所

地址: 辽宁省大连市中山路 457 号

邮编: 116023

电话: 0411-84379738

传真: 0411-84375940

E-mail: catbior2013@dicp.ac.cn

(第二届国际生物质催化炼制大会组委会) 